\title{
Transitioning to lead-free ammunition use in hunting: socio-economic and regulatory considerations for the European Union and other jurisdictions
}

\author{
Niels Kanstrup ${ }^{1 *}$ (I) and Vernon G. Thomas ${ }^{2}$
}

\begin{abstract}
Background: Hunting throughout the European Union (EU) has left an accumulating legacy of spent lead ammunition that has deleterious toxic effects upon the environment, wild life, and humans who consume hunted game meat. Non-toxic lead substitutes for both rifle and shotgun ammunition have been developed and are required in some EU jurisdictions. Within the EU, at least 28 companies make or distribute non-lead shotgun ammunition, and a further 14 companies distribute non-lead rifle ammunition. However, a broad transition to the use of these products has been resisted by the hunting and ammunition-making communities.

Results and conclusions: It is in the self-interest of these communities to recognize the consequences of externalizing the effects of spent lead ammunition to society, and to make hunting more sustainable and socially acceptable. The paper endorses the ongoing process under the European Commission (EC) to introduce wide and fundamental restrictions on the use, trade and possession of lead ammunition for all types of hunting within 3 years, and within 5 years for clay target shooting. This would align EC regulations on lead from ammunition with lead from other anthropogenic sources, and EC regulations that protect the natural environment, especially the conservation of wild birds. Simultaneous EC regulation of lead in marketed game meats would provide extra health protection and assure a safe source of game meat products for consumers.
\end{abstract}

Keywords: European Commission, Hunter resistance, Non-lead substitutes, Product demands, Pollution externalization, Game food standards

\section{Introduction}

Hunters comprise a small minority (less than $2 \%$ ) of the European society, but have for centuries externalized the problems associated with discharged ammunition to the environment and its inhabitants [1]. The cumulative body of evidence that spent lead ammunition from recreational hunting poses a toxic risk to waterbirds, nonwetland/upland birds, scavengers, and humans who eat

\footnotetext{
*Correspondence: nk@bios.au.dk

1 Department of Bioscience, Aarhus University, Grenåvej 14, 8410 Rønde, Denmark

Full list of author information is available at the end of the article
}

hunted game meat is incontrovertible $[2,3]$ and demonstrates the unsustainable use of such ammunition $[1,2$, 4-6]. Discharge of spent lead hunting ammunition now constitutes the largest unregulated release of lead to environments [7]. Despite the long-term recognition of this toxic risk to wildlife in particular, and the availability of lead-free non-toxic substitutes for shotgun and rifle ammunition, a regulated transition to the use of these substitutes is slow, and until now almost exclusively for wetland hunting [8].

There is no consistent pattern to the phase-out of lead ammunition use in the European Union and beyond, and a wide range of regulative actions exists. While Denmark 
and The Netherlands have made most progress in restricting lead shotgun ammunition use, Poland, Ireland and Greece have enacted no restriction. Only Germany requires the use of lead-free rifle ammunition in some jurisdictions [8]. The decision of the UK Waitrose supermarket chain to sell only game meat killed with lead-free ammunition [9] indicates a preparedness of the marketplace to intervene on the issue of lead ammunition use, mainly out of concern about risks to human health from ingested lead and liability.

Given the enormous body of scientific evidence of the toxic effects of lead on humans and wildlife [1], it is paradoxical that lead ammunition use in hunting has eluded much regulation. This is due to lead effects on humans and wildlife being regulated via human health agencies and wildlife agencies, respectively, and the disconnect between them. Not even the United Nations Environment Program has prioritized this recognized issue in its current lead reduction initiatives [10-12]. However, lead used for hunting is now known to have major health implications for consumers of game $[13,14]$ and is regarded to be a One Health issue [1].

The European Green Deal [15] defines a zero pollution ambition for a toxic-free environment to protect Europe's citizens and ecosystems, and sets ambitions for the EU to better monitor, report, prevent, and remedy pollution from air, water, soil, and consumer products. Accordingly, the European Chemicals Agency (ECHA), mandated by the European Commission (EC), has proposed a restriction of lead shot over wetlands to be agreed in 2020, and currently prepares a restriction on lead ammunition in general (including lead shot in terrestrial habitats), with the earliest adoption if agreed by member states by end of 2022 [16, 17]. These actions by the European Commission, based on ECHA [16], may result in wide and fundamental restrictions on the use, trade and possession of lead ammunition, especially if maximum levels of lead in game meat are introduced and harmonized with those for domesticated animal meat products, as advised by Thomas et al. [18].

Any new EC-level regulation must be based on thorough analysis of the best pathway towards a complete transition to lead-free hunting ammunition. This paper rests on the premise that a regulated transition to the use of lead-free ammunition is warranted and inevitable, especially given existing EC restrictions on other anthropogenic sources of lead. The paper provides a partial framework for the regulation of lead ammunition in the EU from a socio-economic and legal perspective for consideration by EC policy makers and regulators. These same considerations are then applied to other jurisdictions in which reductions in lead ammunition use are possible.

\section{The hunting and shooting communities}

In the EU and other Western regions, hunting over the past half century has developed almost exclusively as a leisure activity performed by a small minority of people. European hunters comprise c. $1.8 \%$ of the population, ranging from less than $0.2 \%$ in Belgium and the Netherlands to almost $6 \%$ in Finland and Cyprus: Ireland has the highest level (8.3\%) [19]. However, hunters' numbers are declining in most European countries [20]. Many hunters perceive and defend hunting as an established tradition, and hunters' self-perception is ingrained in this tradition. This tradition is conservative, resistant to change, and not proactive [5, 21, 22]. This makes hunting vulnerable when the surrounding community values are changing rapidly in directions that make hunting more difficult to integrate and sustain politically.

The practice of hunting in Europe has not been subjected to much environmental regulation in terms of setting limits for release of deleterious chemicals. However, there are some specific areas where it is in the hunters' clear self-interest to show a greater adaptability to changing social attitudes, as in the issue of lead from hunting ammunition. The original purpose of hunting was to provide food for the community, and this remains intuitive for many Europeans, including people with no immediate connection to hunting. In some consumer groups, the trend is towards changing traditionally farmed foods with organic products, or wild-harvested products. This is motivated by ethical concerns for animal welfare in traditional agriculture and low-fat quality foods. The issue of food and consumer health affords hunters the opportunity to act constructively with society. This opportunity to supply Europeans with uncontaminated food is in the hunters' unconditional self-interest and a powerful argument for maintaining hunting.

Although the public supply of game meat appears limited in quantity, the annual tonnage of marketed game meat is significant. Recently, 10 European-Scandinavian-Eurasian nations reported an annual import of game meat exceeding 270,000 tonnes [23], despite several nations that have large game markets, such as the UK, France, Austria, and Hungary not being included in the data. Thomas et al. [18] estimated that European hunters shoot over 5.3 million large game mammals and over 80 million birds that support a game meat market supplying 5 million citizens. Hence, the hunters' opportunity to promote their image as suppliers of a valuable food is clear. However, it is crucial that hunters as primary producers $^{1}$ and the subsequent processing chain fully

\footnotetext{
1 "REGULATION (EC) No. 852/2004 OF THE EUROPEAN PARLIAMENT AND OF THE COUNCIL of 29 April 2004 on the hygiene of foodstuffs" link https://eur-lex.europa.eu/legal-content/EN/TXT/?uri=celex:32004R0852, which declares hunters as these primary producers and further outlines their collective responsibilities towards food safety of their products.
} 
guarantee the quality and health safety of such food. This warrants a lead-free and otherwise safe content of game meat on the part of hunters and food processors in light of consumers' increasing interest in health-safe foods. Lead is of major concern because its presence in game meat can be traced back directly to contamination from lead ammunition, and verified using isotope analysis [24].

That lead causes adverse impacts on human health has been known for millennia. Concerns about lead from hunting ammunition negatively impacting wildlife, ecosystems and human health has become more evident during the last century [2]. It is paradoxical that hunters, their national and international organizations, and responsible governments have not played a more pronounced and proactive role to require the use of existing, non-toxic, and effective alternatives. Although some governments partly regulated some lead ammunition use, there is only poor documentation of the enforcement and compliance with such regulations. The general picture is poor progress, especially since several European countries have taken no initiative to limit this source of contamination [8].

The intransigence of the hunting communities has inhibited progress at the socio-political level [25] despite awareness of the consequences of lead ammunition use [26]. However, a large and increasing body of literature has emphasized the multiple benefits that would accrue from a transition [2]. Nevertheless, there remains a need to persistently document and communicate such benefits to the hunters and their communities to enlighten the apparent related self-interest. Sparing millions of wild animals from death from lead toxicosis is in the selfinterest of a community whose activity is based on the sustainable harvest of wildlife populations [25]. Preventing suffering of wild animals from sub-lethal lead intoxication is also in the direct interest of hunters, not least by complying with legal provisions and the public expectation of hunting to not cause un-necessary suffering.

Continued use of lead ammunition constitutes an irreversible contamination of natural habitats. Such type of environmental damage is addressed potentially by $\mathrm{EU}$ Directive 2004/35/(April 2004) on environmental liability with regard to the prevention and remedying of environmental damage, which is based on the "polluter-pays principle" (Article 1). Should hunters be identified as "polluters", they risk the costs of remediation. If not, such externalized costs fall on society [5], thus risking further loss of favourable public perception of hunting. Not least, the elimination of risks of lead exposure among human consumers of game meat could promote the interests of hunters in sustaining their role of supplying society with a unique food and documented to be pivotal in sustaining the public perception of hunting [27]. This single argument manifests the hunters' undisputable self-interest in substituting toxic with non-toxic ammunition.

Non-lead ammunition is regarded by many hunters with scepticism due to many years of biased information campaigns led mostly by the lead manufacturing industry [1]. For example, the Association of European Manufacturers of Sporting Ammunition (AFEMS) and the World Forum on Shooting Activities (WFSA) stated that ".. metallic lead in ammunition has no significant impact on human health and the environment as compared to other forms of lead. Lead fragments in game meat, if ingested, cannot be directly absorbed by the human body because they are in metallic form" 2 a statement that made AFEMS flag the headline "Lead makes you beautiful and HEALTHY". ${ }^{3}$ Competing hunters' organizations have also circulated biased information on non-lead ammunition performance and price $[5,22]$. All these claims have been studied and refuted [28]. Thus, non-lead shot cartridges and rifle ammunition are available for purchase in most European countries [29-31], but the product range of lead-free shotgun ammunition in countries with partial regulations is restricted compared to lead shot brands [31]. These studies concluded that availability of nonlead ammunition is not limited by production, but by demand at the national, regional, and local levels. Some alternative types, including bismuth and tungsten based, gunshot are significantly more expensive than lead shot cartridges. However, in terms of the overall budget of hunters, the cost of ammunition plays a minor role [29]. Furthermore, steel shot-the most common alternative shot-could become significantly cheaper than traditional lead shot when an end to present manufacturing patents will lower production costs substantially. This favours the interest of hunters by lowering potential costs of a transition and indicates that some non-lead ammunition in the long term will become significantly cheaper than traditional lead types.

In order to promote change, hunters should regard the transition to lead-free ammunition as advantageous, not disadvantageous to their self-interest. Once the transition is established, the greater demand for non-lead ammunition will stimulate development and production, thus increasing product diversity and availability. This process will be self-reinforcing, and an economy of scale will further moderate prices. The main obstacle to realization of this socio-economic mechanism is the unwillingness of governments to act on regulation, and apparent lack of

\footnotetext{
${ }^{2}$ AFEMS/WFSA 2015. Symposium, "The sustainable use of lead ammunition in hunting and sports shooting: Facts and emotions" press release. http:// www.leadsymposium.eu/en/the_symposium/press_release.aspx.

3 https://www.euractiv.com/section/health-consumers/opinion/lead-makes -you-beautiful-and-healthy/.
} 
awareness in the hunters' communities. A Danish questionnaire 2020 survey (Kanstrup, unpublished) revealed that $82 \%$ of Danish rifle hunters $(n=2679)$ had "no" or "little" concern about the risks connected to lead in rifle ammunition, whereas about half had "some" or "comprehensive" knowledge of the non-lead rifle ammunition that is widely available in Denmark [32]. There is a need via education and extension to emphasize advantages to hunters from reduced environmental pollution and reduced lead exposure to wildlife and humans through a transition from lead to non-lead rifle ammunition.

\section{The ammunition industry and trade}

The industries suppling European hunters with ammunition comprise a national and international complex. Few, if any, produce all ammunition components themselves. Most assemble ammunition from components purchased from suppliers specialized in production of single components, i.e. primed case/shells, propellants, shot, bullets, and cartridge wads. Most manufacturers make a wide selection of ammunition, including types of ammunition for both hunting and sport shooting and competition. Additionally, many factories supply ammunition for the police, security services and/or the military. The share of ammunition for hunting comprises for most manufacturers a minor part of their production, especially compared with ammunition for clay target shooting.

Many European countries with well-established hunting have no national ammunition manufacture and rely on specialized export/import businesses to supply retail markets. Agencies handling the transfer of ammunition from production to consumption are mostly organized in groups to stimulate trade, and thus achieve monopoly and discount advantages on certain brands. However, despite such systems, ammunition may be traded in parallel routes, and in some cases, directly from the manufacturer to the consumer. The whole system of production, handling, transport, trade and sale of ammunition is highly complex and primarily commercial, thus rather steered by strategies to optimize profit than to sustain hunting and nature conservation. Only a few ammunition manufacturers have recognized their clear self-interest in sustaining a long-term business strategy by supporting the sustainability of hunting and shooting through supplying the transition to non-lead ammunition with products that meet toxicological criteria.

North American and European national and regional regulative demands for the use of non-lead shotgun and rifle ammunition in hunting from the mid-1980s to the present [33], have forced industry to develop substitutes for lead-based ammunition. Manufacturers have been successful in this quest, and there is now a range of nonlead types of shotgun and rifle ammunition suited for all categories of European hunting and target shooting [29, 31]. ${ }^{4}$ It is important to note that any species of game that may be hunted with lead-based shotgun or rifle ammunition can be hunted successfully with non-lead equivalents. The availability of these non-lead products is crucial for a successful transition. A wide "product availability" exists, meaning that the ammunition industry has already created effective lead ammunition substitutes that are effective and cost-competitive [29, 31, 34]. However, industry produces only according to assured market demands (Fig. 1). Thus "market availability", i.e. the diversity and volume of products offered at the consumer/ retail level, may be limited, as concluded by Kanstrup and Thomas [31] who found that stocks of non-lead ammunition held in local European retail shops may be limited in variety, quantity, specification, and brand.

From the industry's perspective, the demand issue is central to a successful transition. It stimulates competition among producers, product development, and competitive pricing. Large-scale demands for a given product facilitate a producer's changing the assembly process from one cartridge gauge/calibre to another; including the quality testing that is required. A partial requirement (only certain areas/taxa), and voluntary adoption of non-lead ammunition by hunters, offer no assurance of product demand [35], an assurance that only regulation and enforcement can provide (Fig. 1). In spite of the prevailing European "patchwork" regulation of lead ammunition, 28 companies already market non-lead shotgun ammunition in Europe [31], and 14 companies market non-lead rifle ammunition in a wide range of calibres and bullet types [30].

The manufacture of steel shot has occurred mainly in China and is more expensive to produce than traditional lead shot. However, a patented US method for manufacturing small steel gunshot (especially $2-3 \mathrm{~mm}$ diameter) by atomization provides a cheaper product. This patent expired in 2019 thus enabling other manufacturers to make steel shot cartridges at lower costs, especially those designed for clay target shooting. Acting on this opportunity would demonstrate the European ammunition manufacturers' innovation and sincere interest in providing hunters and shooters with non-toxic products.

\footnotetext{
${ }^{4}$ Non-lead rifle ammunition is produced using the same brass cartridge cases, primers, and propellants as those used for lead-based ammunition. Only the bullets are made from non-lead material, usually pure copper, or a 95\% copper-5\% zinc alloy. Steel shot shotgun cartridges require different propellants, and different shot wads than their lead shot equivalents. However, non-lead shotgun cartridges using shot made from bismuth-tin shot or tungsten plastic shot are produced using identical components as equivalent lead shot cartridges.
} 


\section{THE DEMAND PICTURE}

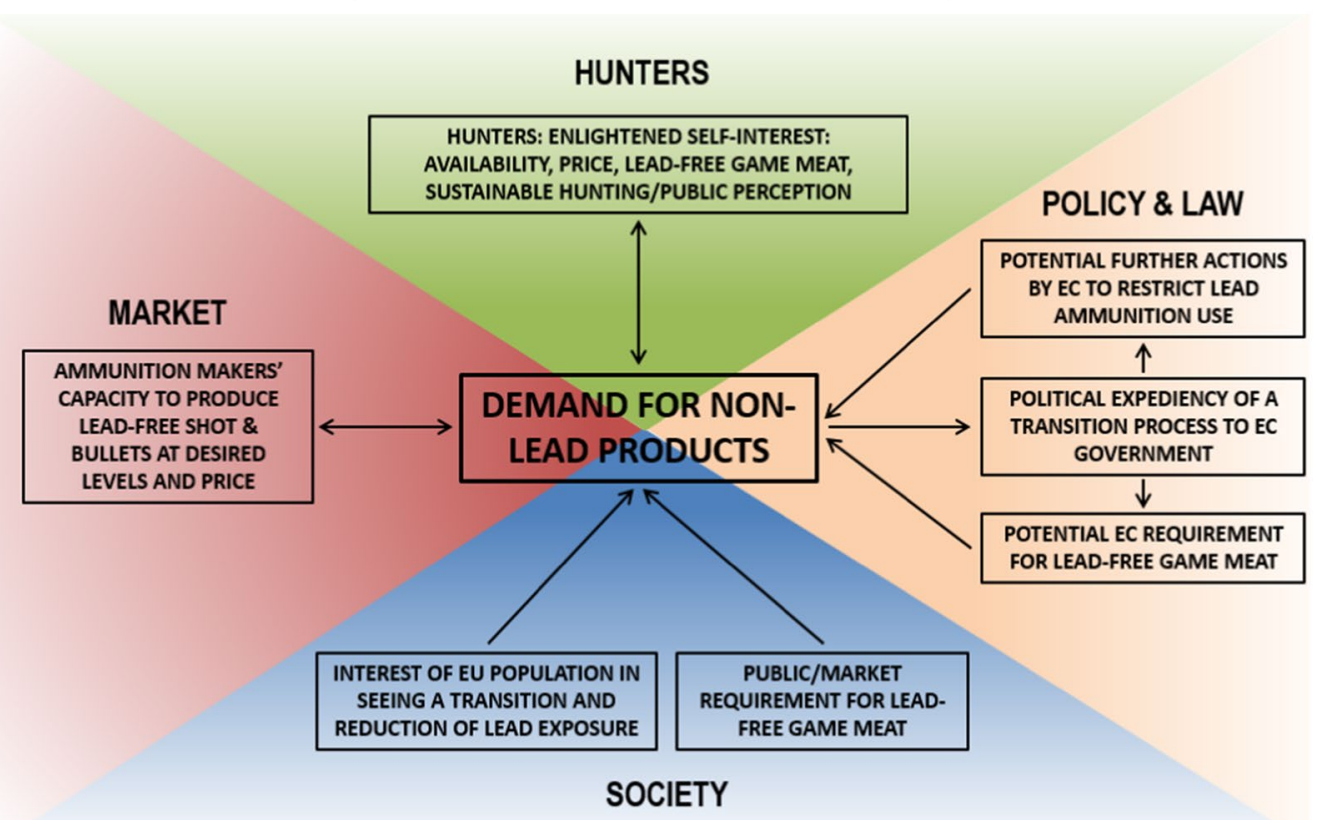

Fig. 1 The four major components that interact to determine the demand for non-lead ammunition products

\section{Role of the European Commission}

The European Union is a political body that has the tradition and power authority to establish policies and laws to benefit the European community's economy, business, social welfare, health, food safety, and conservation of the natural environment. Until recently, the EU has not acted on the issue of lead in ammunition, despite the Union's ratification of, or being party to, several Multinational Environmental Agreements that have taken proactive steps to support the phase-out of lead ammunition, e.g. the United Nations Convention on Migratory Species (CMS), and the African Eurasian Waterbird Agreement (AEWA). While such agreements could stimulate EC policy development, they lack regulatory authority.

In 2017, the European Commission requested the European Chemicals Agency (ECHA) to prepare an Annex $\mathrm{XV}$ report to propose a restriction on lead gunshot in wetlands under the EU REACH (Registration, Evaluation, Authorisation and Restriction of Chemicals) Regulation [17]. The Commission initiative to restrict lead in ammunition in EU derives from the European Green Deal [15] which defines a zero pollution ambition for a toxic-free environment to protect Europe's citizens and ecosystems, and sets ambitions for the EU to better monitor, report, prevent and remedy pollution from air, water, soil, and consumer products. The Annex XV report was adopted by ECHA's scientific committees (including the Committee for Socio-Economic Analysis) in June, 2018, prior to being considered by the REACH Committee (comprising Member State representatives). In September 2018, ECHA concluded that additional measures were needed to regulate the use of lead ammunition in terrestrial environments and lead fishing weights [16]. The need for this extension was motivated by several arguments including that it would: limit additional pollution with lead and improve the quality of the environment; reduce the mortality of an estimated 1 to 2 million birds, such as pheasants and partridges and scavenging and predator species that consume lead-poisoned birds; and reduce health risks to hunters and their families who frequently eat game meat killed with lead shot or bullets. In October, 2019, the extended proposal was published in a call for evidence with a deadline at December, 2019. The present status is that two REACH restrictions are on their way: (1) the restriction of lead shot over wetlands to be agreed by member states, which cannot be amended anymore; and (2) the restriction on lead ammunition in general including lead shot in terrestrial habitats (and also including lead in fishing gear) currently being developed by ECHA, which will be commented by REACH committees and the public by January 2022 with the earliest adoption if agreed by member states by end of 2022 . 
All EC regulations apply directly at the national level. Thus, when any EU-level approved regulation enters into force, it becomes directly and immediately applicable within all 27 member countries, including their government, administration, businesses, and citizens. Should an EC initiative to regulate lead ammunition and fishing weights under the REACH come into force, a process to begin the transition would begin across all 27 member states, including non-EU countries that have ratified $\mathrm{REACH}$, i.e. Norway, Iceland and Liechtenstein.

Countries do not need to create their own legislation to bring such EU legal act into force. However, the single countries hold the formal responsibility to ensure enforcement. Therefore, each EU Member State (and Norway, Iceland and Liechtenstein) must establish an official system of controls and identify legislation specifying penalties for non-compliance with the provisions of REACH. The ECHA hosts the Forum for Exchange for Information on Enforcement (Forum) composed of representatives of national enforcement authorities to coordinate the enforcement of REACH.

Approximately 18,000-21,000 tonnes of lead gunshot have been added to European natural ecosystems annually and have accumulated over the past 1-2 centuries. This lead becomes solubilized in lower $\mathrm{pH}$ waters and sediments and constitutes a permanent source of pollution [36,37]. A regulated transition to non-lead ammunition use in the EU would complement related EU environmental initiatives such as the EU Water Framework Directive, the EU Birds Directive, and other agreements (the Bonn Convention, the Ramsar Convention and the AEWA) to which it is a party [38, 39].

The European Commission has other legal instruments that could support the transition at the EU level. EC Regulation No 1881/2006 of 19 December, 2006, sets maximum levels for certain contaminants in foodstuffs. This act sets maximum levels of lead allowed in traded meat from bovine animals, sheep, pigs and poultry, wild cephalopods, and bivalve molluscs, but not from wild game animals. Setting maximum levels of lead game meat in harmony with EC regulations on lead in domestic meats and offal is important as a complementary measure to the regulation of the trade and use of lead ammunition because it would harmonize heath protection standards for traded game meat across the EU and protect people who consume game meat. Maximum levels would also provide a mechanism for measuring compliance with regulations of the use of lead ammunition through the enforcement, inspection, and monitoring programmes conducted by Member States [18].

\section{Proposed EC regulated phase-in schedule for non-lead ammunition}

Assuming that the EC will enforce a REACH restriction on all lead ammunition, a realistic schedule for implementation has to be developed, based on awareness of existing regulations and how they can develop into a permanent EU-wide transition. The greatest need is for lead shotgun ammunition to be phased out for hunting in all habitat types, and for all lead rifle ammunition to be phased out in all hunting applications. The rationales are the same for both categories of hunting: preventing lead exposure from spent ammunition ingestion, preventing lead exposure in humans who consume hunted game animals, and preventing lead accumulation in hunted environments, especially those subject to shotgun shooting [2].

Lead hunting gunshot should be the first because it has the longest record of adverse impacts on wildlife and ecosystems and, therefore, has been subject to multiple international and national regulatory initiatives. In terms of tonnage, the dispersal of lead gunshot in natural ecosystems exceeds by far other sources and causes an irreversible accumulation of lead that constitutes a longterm and uncertain environmental risk [40] and should therefore stop as soon as possible. Safe and efficient alternatives to lead gunshot and rifle bullets are available at prices comparable to traditional lead types and in quantities that will keep pace with increasing market demands [31]. Use of lead shot is already restricted in 23 European countries, and lead rifle ammunition is currently statewide restricted in three states in Germany, where several more states have introduced partial regulation of lead rifle ammunition, e.g. in state forests $[8,41]$.

We therefore fully endorse the ongoing $\mathrm{REACH}$ procedure including the restriction of lead shot over wetlands to be agreed by member states in 2020, and the further restriction on lead ammunition in general currently being developed by ECHA with the earliest adoption by end of 2022. In both cases, a phase-in period of maximum 3 years from the formal adoption of the restrictions is proposed as this would allow for education and awareness programmes for EU hunters through their national and EU-level organizations. These same programmes would address both rifle and shotgun hunters, emphasizing the need for, and benefits of, the transition. This length of time would allow ammunition makers to increase their existing production of non-lead products, and to increase availability within the EU. The amount of rifle ammunition used annually is likely much less than the volume of shotgun cartridges due largely to the nature of each type of hunting (although more than 150 tonnes of lead is dispersed annually into the environment in the EU by hunting with lead bullets [16]). This should 
facilitate the transition to the use of non-lead rifle ammunition within 3 years. The EC would also be advised to set a maximum lead level (ML) in marketed game meat products in harmony with that set for domestic meats under EC Regulation 1881/2006 [42]. This should be an essential complement to the regulation of lead gunshot and rifle bullets [17]. The rationale for the dual regulation is that wild game meat is imported into the EU from nonEU countries (e.g. the United Kingdom and New Zealand) and should comply with an EU regulation allowing access to EU markets. Regulating the use of non-lead ammunition by all hunters would ensure that game would not contain lead, whether consumed by them or entered into retail markets.

Clay target shooting accounts for the largest segment of lead cartridge production, and the transition to non-lead ammunition for this sport has received little consideration [43]. Given the larger amount of non-lead ammunition (i.e. with smaller diameter steel shot) that would need to be produced, and that such competitive shooting is also an Olympic sport, it is proposed that a 5-year transition period (i.e. 2020-2025) be applied to this category of shotgun ammunition. Competition shooting with small and full-bore rifle calibres at shooting ranges where remediation programs are documented and lead residues of ammunition are recycled could proceed without restriction.

An EC regulation per se makes no transition. Although an EU restriction will automatically prohibit imports, enforcement is necessary to ensure compliance at the trade and user level as long as stocks of lead ammunition are available. The construction of the regulation is critical. If the regulation were only partial, and hunters were allowed to transport lead ammunition to, and be in possession of lead ammunition inside hunting areas where only the use of such ammunition is prohibited, enforcement would be difficult and compliance equally poor. Evidence from countries with partial prohibitions of lead shows a low level of compliance [44, 45]. However, a national ban on the possession of lead shot cartridges would promote compliance, as in Denmark [45].

\section{European society and its position on hunting and lead pollution}

The non-hunting segment of the European population exceeds $98 \%$. In a democratic society where formal political decisions are based on simple majorities, the hunting community needs allies among non-hunters to favour decisions that preserve hunting. The public acceptance of hunting has been investigated in very general terms which demonstrate great variation among countries. In a questionnaire, EORG [46] found that national respondents were "Very worried" about hunting and shooting in a range from 5\% (Sweden) to 38\% (Greece). It appears that most national populations are split into three groups: some are generally positive to hunting, some are neither positive nor negative, and some are generally negative. In Denmark, $43 \%$ of the general public had a positive attitude, $31 \%$ were indifferent, and $26 \%$ had a negative attitude to recreational hunting [47]. However, for many people, the attitude toward hunting depends on what the attitude is about. Some of the conditions under which hunting occurs affect attitudes. For instance, hunting of farm-reared and released game birds, hunting organized as a group hunt, and single day leases of hunting grounds have less acceptance than other types of hunting [47]. In a US study, $87 \%$ of respondents agreed that it was acceptable to hunt for food. However, only 37\% agreed that it was acceptable to hunt for a trophy [48]. Heberlein and Willebrand [49] found that over 90\% of Swedes supported hunting by native people, but this dropped when hunting was for meat and recreation. Only one third of the Swedes supported hunting when only recreation and sport were given as reasons. This reflects the large majority of non-hunting European public not having a clear overall attitude to hunting, but can be regarded to be highly ambivalent and impressionable.

Changing social attitudes and behaviours may be insensitive to, and conflict with, the interests of hunters. As an example, Europe has regulated an end to the many uses of anthropogenic lead, an environmental action that is well-supported by society because of the understood risks posed by lead to humans. Against this backdrop, it is difficult to reconcile the continued release of many tonnes of un-reclaimed ammunition lead each year, especially in the interests of sport, and the known persistent and adverse impacts on ecosystems, wildlife, and humans who consume game. Changes in types of foods demanded by Europeans are occurring quickly, whether related to organically produced foods, or animal-free foods. The European retail market has recorded a significant growth rate of organic food, and consumer attitudes to meat are changing showing a rise in the number of vegetarians, vegans and flexitarians, with more people now opting for meat-free days $[50,51]$. The changes arise out of ethical concerns about food production, environmental impacts of agriculture, and personal diet/health considerations. It is relevant, here, to note that despite the declining demand for farmed meat there is a growing consumption of wild game meat in many European countries, e.g. Germany and the UK $[52,53]$ largely because such food is seen to have lived a better life than domestic animals, and its comparative nutritional value [54]. This growing market appears to be readily sustained by abundant and increasing populations of European deer species and wild boar (Sus scrofa) $[20,55]$. This market provides a 
great opportunity to support recreational hunting, especially if game is taken with non-lead ammunition, thereby enhancing the pollution-free status of the meat.

Hunting and clay target shooting have the inevitable consequence that gunshot, wads and bullets are unavoidably dispersed into the environment. This amounts, annually, to over 40,000 tonnes lead in EU. Limited documentation exists on the costs of clean-up of spent ammunition parts (lead shot, plastic wads, and cartridge cases) from hunting and sport shooting. As to the latter, Kajander and Parri [56] presented available techniques for the management of environmental impacts at shooting ranges, including maintenance measures, remediation and design features for new ranges. Such management activities may be very costly, especially at the level of the individual shooter. Few estimates exist for complete clean-up costs. However, were all lead contamination from the 10,000-20,000 tonnes of gunshot used annually by sports shooters in the EU to be mitigated, annual costs would be in the region of 81-162 million Euros [14]. This estimate was based on a per tonne figure for clean-up of rifle bullets. Gunshots are more dispersed than bullets and clean-up of gunshot is likely to be considerably more costly than the above estimate. Clean-up of shooting ranges is practised in some places and private services have developed techniques to assist. Clean-up of the 21,000 tonnes of lead shot used annually for hunting would not be practical or economically feasible. To reduce the risks in the most contaminated hunting areas such as regular fixed blinds, Pain et al. [14] assumed that expenditures at least similar to the cost of cleaning up shooting ranges would likely be required.

The potential costs to mitigate impacts of accumulated lead ammunition contamination should, legally, be returned to the hunters and shooters based on the Polluter-pays Principle (e.g. EU Directive 2004/35/, Article 1) although this principle has, in reality, not often been applied. However, few, if any, European hunting or shooting system includes direct charging of the costs for such mitigation, and costs are externalized to the community. In a Danish example, 7000 tonnes of contaminated soil were removed from a surface areas of 0.6 ha at a shotgun shooting range after 50 years' shooting in Langstrup Bog (Fredensborg) in 2019 [57]. The costs (about 1 mil. Euros) were paid by the local municipality because the shooting club responsible was dissolved.

European society is increasingly aware of the importance of recycling metals, driven by concerns over, inter alia, supply, market prices, sustainable resource management, and climate change. That hunting and shooting cause ammunition parts to be dispersed into the environment, with no or little possibility of retrieval and recycling, makes these sports un-aligned with common social concerns. This applies to all metals used in ammunition (lead, steel, bismuth, copper, zinc, and tungsten), and society could criticize hunting and shooting for being wasteful of these valuable resources. Consequently, there is need for the hunting and shooting society in cooperation with the ammunition industry to minimize wastage of valuable metals. Lead gunshot comprises the largest tonnage of ammunition, and a transition to steel shot would be the cornerstone in this strategy.

The externalization of costs of remediating dispersal of spent toxic and polluting ammunition from shooting and hunting is poorly recognized by the public. When better documented, and used strategically by non- or anti-hunting groups, this may become a tremendous obstacle to hunters and their interests. The fact that the accumulated pool of a toxic substance that poses a potential threat to wildlife, ecosystems, and humans originates from a small percentage of society, and from a purely recreational activity, only makes the case much more difficult. In societal terms, continued use of lead ammunition undermines a broadly ambivalent public perception of responsible hunting [5]. Society would likely favour a lead ammunition ban, given EU-wide bans on other lead products. Moreover, the existing European capacity to produce non-lead substitutes would favour legislation that would prevent lead problems and their associated costs from being externalized to the public.

\section{Considerations for other international jurisdictions}

Most jurisdictions in the EU and internationally requiring use of non-lead hunting ammunition have acted over concerns with wetland species hunting rather than hunting across all habitats. Although Denmark and The Netherlands have banned use of lead shotgun ammunition, lead rifle ammunition is still allowed in these countries. In North America, hunters are required, nation-wide, to use non-lead ammunition to hunt only migratory waterfowl (the USA since 1991; Canada, since 1999) [33]. California is, since 2019, the only jurisdiction to require non-lead ammunition use for all categories and species of hunting, mainly to protect several avian scavenging species [33]. Globally, no national-level jurisdiction has linked regulation of lead ammunition to public health concerns, although several German states require nonlead rifle ammunition use for this reason [4].

The sale of hunted wild game is a largely European phenomenon. However, hunting with lead-based ammunition for personal consumption is a common practice in many non-European countries, and native and nonnative people who rely on wild game for their principal food intake are especially at risk from dietary lead exposure. This is the case in Alaska, USA [58], Canada [5961], and Greenland [62]. In Alaskan children, the cause 
of high blood lead levels could be attributed to consumption of lead-contaminated game meat and hunting households in over half of cases examined [58]. Large numbers of birds (species of doves and ducks) shot in high-volume hunts (1000-2000 birds/hunter/day) are also given to local communities in Argentina who are subsequently exposed to ingested lead [63]. The remains of trophy animals killed in African countries are routinely distributed to nearby communities, together with the residues of lead in the carcasses [64]. These examples of lead exposure are entirely preventable by the use of non-lead ammunition, but few of the jurisdictions listed above have taken any action on this issue. Large numbers of animals are killed as pests by culling operations in various countries. The carcasses may be eaten by people or left for consumption by scavengers, which are also subjected to lead exposure and subsequent mortality [65]. Avian scavengers and predators that consume the remains of hunted animals are, globally, frequently exposed to lead from spent ammunition [6]. A transition to non-lead ammunition use by hunters would, simultaneously and immediately, benefit the health of these birds besides the humans who consume game.

There is clear need to regulate the transition to use of non-lead products for all types of hunting to protect not only human and wildlife health, but also to reduce aquatic and soil pollution. It is in the socio-political interests of all hunting communities to do so [5]. Should the EC regulate lead ammunition use, international hunting agencies such as the European Federation for Hunting and Conservation (FACE) and the International Council for Game and Wildlife Conservation (CIC) could facilitate the adoption of non-toxic lead ammunition among member states, especially given their focus on the sustainability and value of hunting, and the endorsement of the CIC by various United Nations agencies. The recent declaration by the British Association for Shooting and Conservation [66], and its endorsement by related United Kingdom associations, that a transition to non-lead shotgun ammunition is now justified, is an important step in facilitating this process.

\section{Conclusions}

Lead from spent ammunition affects adversely the health of the environment, its wildlife, and humans. Effective non-lead substitutes exist for both shotgun and rifle shooting and are becoming increasingly available. Their voluntary adoption by hunters has been resisted, and it will require regulation at the EU level to effect the transition to non-lead ammunition use and to prevent further externalization to society of the problems and costs of accumulated lead. It is in the enlightened self-interest of hunters to respond, thereby increasing demands for non-lead products that industry can provide, to make hunting be more socially responsible and sustainable, and to provide game meat products that are safe for consumers. The ongoing EC regulation under a $\mathrm{REACH}$ restriction of lead gunshot in wetlands (2020) and all other types of ammunition in any habitats (2022) should take effect within a maximum of 3 years from the adoption of the restrictions, although within a of maximum 5 years for clay target shotgun shooting at ranges. The amendment of EC Regulation 1881/2006 to require mandatory lead MLs for all game meats would be a vital complement to the regulated transition to non-lead ammunition. This dual regulation would prevent lead-contaminated game meat from entering the European Union from both within the Union and imports from non-EU countries. The regulatory proposals advanced in this paper for the EU have direct relevance to other international jurisdictions where hunting is practised, and especially where people are at risk from lead ingestion by frequent consumption of game meats, and scavenging species are exposed to lead in the remnants of shot animals. These proposals are entirely consistent with, and complement, the environmental ambitions of the EU for a non-toxic environment and the United Nations 2030 Agenda for Sustainable Development $[12,15]$.

\section{Abbreviations \\ AEWA: African Eurasian Waterbird Agreement; AFEMS: Association of European Manufacturers of Sporting Ammunition; CIC: International Council for Game and Wildlife Conservation; CMS: United Nations Convention on Migratory Spe- cies; EC: European Commission; ECHA: European Chemicals Agency; EU: Euro- pean Union; FACE: European Federation for Hunting and Conservation; ML: Maximum level; REACH: Registration, Evaluation, Authorisation and Restriction of Chemicals; WFSA: World Forum on Shooting Activities.}

\section{Acknowledgements}

We thank the three peer reviewers for their diligent reviews and helpful comments on an earlier draft.

\section{Authors' contributions}

Both authors contributed equally to the concept of the paper, the research behind it, its composition, and submission. Both authors read and approved the final manuscript.

\section{Funding}

Funding was provided by the personal financial resources of the authors. Aarhus University, Department of Bioscience, kindly funded the Open Access publication.

\section{Availability of data and materials}

Not applicable.

Ethics approval and consent to participate

Not applicable.

Consent for publication

Not applicable.

Competing interests

The authors declare that they have no competing interests. 


\section{Author details}

${ }^{1}$ Department of Bioscience, Aarhus University, Grenåvej 14, 8410 Rønde, Denmark. ${ }^{2}$ Department of Integrative Biology, College of Biological Science, University of Guelph, Guelph, ON N1G 2W1, Canada.

Received: 17 March 2020 Accepted: 15 June 2020 Published online: 24 June 2020

\section{References}

1. Arnemo JM, Andersen O, Stokke S, Thomas VG, Krone O, Pain DJ, Mateo $\mathrm{R}$ (2016) Health and environmental risks from lead-based ammunition: science versus socio-politics. EcoHealth 13:618-622. https://doi. org/10.1007/s10393-016-1177-x

2. Kanstrup N, Thomas VG, Fox AD (2019) Lead in hunting ammunition: persistent problems and solutions. Special Issue. Ambio 48(9):923-1098

3. Pain DJ, Swift J, Green R, Cromie R (2020) The tide is turning for lead ammunition. Br Birds 113:110-118

4. Gerofke A, Martin A, Schlichting D, Gremse C, Müller-Graf C (2019) Heavy metals in game meat. In: Rietjens IMCM, Rose MD, Smulders FJM (eds) Chemical hazards in foods of animal origin. Food safety assurance and veterinary public health, No. 7. Wageningen Academic Publishers, Wageningen, pp 585-609. https://doi.org/10.3920/978-90-8686-877-3_24

5. Kanstrup N, Swift J, Stroud DA, Lewis M (2018) Hunting with lead ammunition is not sustainable: European perspectives. Ambio 47(8):846-857. https://doi.org/10.1007/s13280-018-1042-y

6. Krone O (2018) Lead poisoning in birds of prey. In: Sarasola JH, Grande JM, Negro JJ (eds) Birds of prey: biology and conservation in the XXI century. Springer, Cham, pp 251-272. https://doi.org/10.1007/978-3-31973745-4_11

7. ECHA (2019) ECHA newsletter November 2019-February 2020. https:// newsletter.echa.europa.eu/home/-/newsletter/entry/terrestrial-envir onments-also-being-polluted-with-lead-ammunition. Accessed 1 Dec 2019

8. Mateo R, Kanstrup N (2019) Regulations on lead ammunition adopted in Europe and evidence of compliance. Ambio 48:989-998. https://doi. org/10.1007/s13280-019-01170-5

9. Barkham P (2019) Waitrose stops sale of birds shot with lead as experts call for UK ban. The Guardian. https://www.theguardian.com/busin ess/2019/jul/29/experts-call-for-ban-on-lead-shot-as-waitrose-overhaulssale-of-game. Accessed 17 Dec 2019

10. Thomas VG, Guitart R (2016) Exposure to lead through ammunitionneed to revise strategies. Environ Policy Law 46:127-131. https://doi. org/10.3233/EPL-46202

11. UNEP (2017) Towards a pollution-free planet. Background report. Nairobi. https://www.unenvironment.org/resources/report/towards-pollutionfree-planet-background-report. Accessed 4 Mar 2020

12. UNEP (2019) Global chemicals outlook II. From legacies to innovative solutions. Implementing the 2030 agenda for sustainable development. Geneva

13. Green RE, Pain DJ (2019) Risks to human health from ammunitionderived lead in Europe. Ambio 48:954-968. https://doi.org/10.1007/s1328 0-019-01194-x

14. Pain DJ, Dickie I, Green RE, Kanstrup N, Cromie R (2019) Wildlife, human and environmental costs of using lead ammunition: an economic review and analysis. Ambio 48:969-988. https://doi.org/10.1007/s13280-01901157-2

15. EC (2019) The European Green Deal. Communication from the Commission to the European Parliament, The European Council, The Council, The European Economic and Social Committee and the Committee of Regions. The European Commission, COM 640. https://ec.europa.eu/info/ sites/info/files/european-green-deal-communication_en.pdf. Accessed 20 Dec 2019

16. ECHA (2018) A review of the available information on lead in shot used in terrestrial environments, in ammunition and in fishing tackle. https:// echa.europa.eu/documents/10162/13641/lead_ammunition_investigat ion_report_en.pdf/efdc0ae4-c7be-ee71-48a3-bb8abe20374a. Accessed 17 Dec 2019

17. Treu G, Drost W, Stock F (2020) An evaluation of the proposal to regulate lead in hunting ammunition through the European Union's REACH regulation. Environ Sci Eur 32:68. https://doi.org/10.1186/s12302-02000345-2

18. Thomas VG, Pain DJ, Kanstrup N, Green RE (2020) Setting maximum levels for lead in game meat in EC regulations: an adjunct to replacement of lead ammunition. Ambio. https://doi.org/10.1007/s13280-020-01329-5

19. FACE (2020) Web page. https://www.face.eu. Accessed 17 Jan 2020

20. Massei G, Kindberg J, Licoppe A, Găcić D, Šprem N, Kamler J, Baubet E, Hohmann U, Monaco A, Ozolinš J et al (2014) Wild boar populations up, numbers of hunters down? A review of trends and implications for Europe. Pest Manage Sci 71:492-500. https://doi.org/10.1002/ps.3965

21. Newth JL, Lawrence A, Cromie RL, Swift JA, Rees EC, Wood KA, Strong EA, Reeves J, McDonald RA (2019) Perspectives of ammunition users on the use of lead ammunition and its potential impacts on wildlife and humans. People Nat 1:347-361. https://doi.org/10.1002/pan3.30

22. Cromie R, Newth J, Reeves J, O'Brien M, Beckmann K, Brown M (2015) The sociological and political aspects of reducing lead poisoning from ammunition in the UK: why the transition to non-toxic ammunition is so difficult. In: Delahay RJ, Spray CJ (eds) Proceedings of the oxford lead symposium: lead ammunition: understanding and minimizing the risks to human and environmental health. Edward Grey Institute: Oxford University, pp 104-124. http://www.oxfordleadsymposium.info/wp-conte nt/uploads/OLS_proceedings/papers/OLS_proceedings_cromie_newth _reeves_obrien_beckman_brown.pdf

23. FAO (2018) Game meat. production and trade in the ENECE region. Food and Agricultural Organization of the United Nations. Rome, Italy. https ://www.unece.org/fileadmin/DAM/timber/meetings/2018/20180321/ game-meat-draft-2018-03.pdf. Accessed 17 Jan 2020

24. Tsuji LJS, Wainman BC, Martin ID, Sutherland C, Weber J-P, Dumas P, Nieboer $E$ (2008) The identification of lead ammunition as a source of lead exposure in first nations: the use of lead isotope ratios. Sci Total Environ 393:291-298. https://doi.org/10.1016/j.scitotenv.2008.01.022

25. Arnemo JM, Cromie R, Fox AD, Kanstrup N, Mateo R, Pain DJ, Thomas VG (2019) Transition to lead-free ammunition benefits all. Ambio 48(9):10971098. https://doi.org/10.1007/s13280-019-01221-x

26. Kanstrup N (2009) (ed) Sustainable hunting ammunition. In: Proceedings of workshop sustainable hunting ammunition, Aarhus 2009. Aarhus, Denmark. http://www.cic-wildlife.org/wp-content/uploads/2013/04/ CIC_Sustainable_Hunting_Ammunition_Workshop_Report_low_res.pdf. Accessed 1 Dec 2019

27. Ljung PE, Riley SJ, Heberlein TA, Ericsson G (2012) Eat, prey, and love: game meat consumption and attitudes towards hunting. Wildl Soc Bull 36:669-675. https://doi.org/10.1002/wsb.2008

28. Thomas VG, Kanstrup N, Gremse C (2015). Key questions and responses regarding the transition to use of lead-free ammunition. In: Delahay RJ, Spray CJ (eds) Proceedings of the Oxford lead symposium. lead ammunition: understanding and minimising the risks to human and environmental health, Edward Grey Institute, University of Oxford, UK, pp 125-133. http://www.oxfordleadsymposium.info/wp-content/uploads/OLS_proce edings/papers/OLS_proceedings_thomas_kanstrup_gremse.pdf

29. Thomas VG (2015) Availability and use of lead-free shotgun and rifle cartridges in the UK, with reference to regulations in other jurisdictions. In: Delahay RJ, Spray CJ (eds) Proceedings of the Oxford lead symposium. Lead ammunition: understanding and minimising the risks to human and environmental health, Edward Grey Institute, University of Oxford, UK, pp 85-97. http://www.oxfordleadsymposium.info/wp-content/uploads/ OLS_proceedings/papers/OLS_proceedings_thomas.pdf

30. Thomas VG, Gremse C, Kanstrup N (2016) Non-lead rifle hunting ammunition: issues of availability and performance in Europe. Eur J Wildl Res 62:633-641. https://doi.org/10.1007/s10344-016-1044-7

31. Kanstrup N, Thomas VG (2019) Availability and prices of non-lead gunshot cartridges in the European retail market. Ambio 48(9):1039-1043. https://doi.org/10.1007/s13280-019-01151-8

32. Kanstrup N, Haugaard L (2020) Krav til projektilvægt, anslagsenergi m.v. for riffelammunition, der anvendes til jagt og regulering. bind 36, Fagligt notat fra DCE - Nationalt Center for Miljø og Energi. https://dce.au.dk/ fileadmin/dce.au.dk/Udgivelser/Notatet_2020/N2020_36.pdf (With an English summary)

33. Thomas VG, Kanstrup N, Fox AD (2019) The transition to non-lead sporting ammunition and fishing weights: review of progress and barriers to implementation. Ambio 48:925-934. https://doi.org/10.1007/s1328 0-018-1132-x 
34. Thomas VG (2013) Lead-free hunting rifle ammunition: product availability, price, effectiveness, and role in global wildlife conservation. Ambio 42:737-745. https://doi.org/10.1007/s13280-012-0361-7

35. Thomas VG, Owen M (1996) Preventing lead toxicosis of European waterfowl by regulatory and non-regulatory means. Environ Conserv 23:358-364. https://doi.org/10.1017/S0376892900039229

36. Migliorini M, Pigino G, Bianchi N, Bernini F, Leonzio C (2004) The effects of heavy metal contamination on the soil arthropod community of a shooting range. Environ Pollut 129:331-340. https://doi.org/10.1016/j.envpo 1.2003.09.025

37. Sullivan T, Gottel N, Basta N, Jardine P, Schadt C (2012) Firing range soils yield a diverse array of fungal isolates capable of organic acid production and Pb mineral solubilization. Appl Environ Microbiol 78(17):6078-6086. https://doi.org/10.1128/aem.01091-12

38. Thomas VG, Guitart R (2005) Role of international conventions in promoting avian conservation through reduced lead toxicosis: progression towards a non-toxic agenda. Bird Conserv Int 15:147-160. https://doi. org/10.1017/s0959270905000110

39. Brack W, Ait-Aissa S, Backhaus T, Birk S, Barceló D, Burgess R, Cousins I, Dulio V, Escher BI, Focks A et al (2019) Strengthen the European collaborative environmental research to meet European policy goals for achieving a sustainable, non-toxic environment. Environ Sci Eur 31:63. https://doi.org/10.1186/s12302-019-0232-y

40. Kanstrup N, Fox AD, Balsby TJS (2020) Toxic lead gunshot persists accessible to waterbirds after a 33-year ban on their use. Sci Total Environ. https ://doi.org/10.1016/j.scitotenv.2020.136876

41. Gremse C, Rieger S (2015) Lead from hunting ammunition in wild game meat: research initiatives and current legislation in Germany and the EU. In: Delahay RJ, Spray CJ (eds) Proceedings of the Oxford lead symposium. Lead ammunition: understanding and minimising the risks to human and wild life health, Edward Grey Institute. University of Oxford, UK, pp 51-57. http://www.oxfordleadsymposium.info/wp-content/uploads/OLS_proce edings/papers/OLS_proceedings_gremse_reiger.pdf

42. EC (2006) European Commission Regulation EC 1881/2006. Setting maximum levels for certain contaminants in foodstuffs. Official Journal of the European Union EC 1881/2006 (20.12.2006), L364/365-L364/324. http://eur-lex.europa.eu/legal-content/EN/TXT/?qid=1442063437 890\&uri=CELEX:32006R1881

43. Thomas VG, Guitart R (2013) Transition to non-toxic gunshot use in Olympic shooting: policy implications for IOC and UNEP in resolving an environmental problem. Ambio 42:746-754. https://doi.org/10.1007/ s13280-013-0393-7

44. Cromie R, Loram A, Hurst L, O'Brien M, Newth J, Brown M, Harradine J (2010) Compliance with the environmental protection (restrictions on use of lead shot) (England) Regulations 1999. DEFRA, Bristol, UK. http:// randd.defra.gov.uk/Default.aspx?Menu=Menu\&Module=More\&Locat ion $=$ None $\&$ Project $\mid \mathrm{D}=16075$

45. Kanstrup N (2018) Lessons learned from 33 years of lead shot regulation in Denmark. Ambio 48:999-1008. https://doi.org/10.1007/s1328 0-018-1125-9

46. EORG (2002) The attitudes of Europeans towards the environment. https ://ec.europa.eu/commfrontoffice/publicopinion/archives/ebs/ebs_180_ en.pdf. Accessed 17 Jan 2020

47. Gamborg C, Jensen FS (2017) Attitudes towards recreational hunting: a quantitative survey of the general public in Denmark. J Outdoor Recreat Tour 17:20-28. https://doi.org/10.1016/j.jort.2016.12.002

48. Byrd E, Lee JG, Widmar NJO (2017) Perceptions of hunting and hunters by U.S. respondents. Animals 7(11):83-98. https://doi.org/10.3390/ani71 10083

49. Heberlein TA, Willebrand T (1998) Attitudes toward hunting across time and continents: The United States and Sweden. Game Wildl 15:10711080. http://pascal-francis.inist.fr/vibad/index.php?action=getRecordD etail\&idt=1777661
50. BIOECO (2020) European organic market grew to more than 37 billion euros in 2017. https://www.bioecoactual.com/en/2019/02/18/europeanorganic-market/. Accessed 17 Dec 2019

51. EC (2018) EU Agricultural Outlook. For markets and income 2018-2030. https://ec.europa.eu/info/sites/info/files/food-farming-fisheries/farming/ documents/medium-term-outlook-2018-report_en.pdf. Accessed 16 Jan 2020

52. DJV (2018) Jäger haben mehr Wildbret geliefert. https://www.jagdverban d.de/content/jäger-haben-mehr-wildbret-geliefert. Accessed 10 Jan 2020

53. Mintel (2016) Unprocessed poultry and red meat-UK-October 2016. https://store.mintel.com/unprocessed-poultry-and-red-meat-uk-octob er-2016. Accessed 20 Jan 2020

54. Strazdina V, Jemeljanovs A, Šterna V (2013) Nutrition value of wild animal meat. Proc Latvian Acad Sci Sect B 67(4/5):373-377. https://doi. org/10.2478/prolas-2013-0074

55. Burbaitè L, Csányi S (2010) Red deer population and harvest changes in Europe. Acta Zool Lituanica 20:179-188. https://doi.org/10.2478/v1004 3-010-0038-z

56. Kajander S, Parri A (2014) Management of the environmental impact of shooting ranges. https://www.ecde.info/sites/default/files/docs/ sy_4_2014_en.pdf. Accessed 10 Jan 2020

57. NIRAS (2019) Karlebo Skydebane. Dokumentationsrapport. Fredensborg Kommune December 2019. Projekt ID: 10401296. Document ID: XTAXEUDDNY4W-75177900-785. Fredensborg Municipality, Denmark

58. Bressler JM, Yoder S, Cooper S, McLaughlin J (2019) Blood lead surveillance and exposure sources among Alaska children. J Public Health Manage Pract 25(1Supp):S71-S75. https://doi.org/10.1097/phh.0000000000 00877

59. Levesque B, Duchesne J-F, Gariépy C, Rhainds M, Dumas P, Scheuhammer AM, Proulx J-F, Déry S, Muckle G, Dallaire F, Dewailly É (2003) Monitoring of umbilical cord blood lead levels and sources assessment among the Inuit. Occup Environ Med 60:693-695. https://doi.org/10.1136/ oem.60.9.693

60. Liberda EN, Tsuji LJS, Martin ID, Ayotte P, Robinson E, Dewailly E, Nieboer E (2018) Source identification of human exposure to lead in nine Cree Nations from Quebec, Canada (Eeyou Istchee territory). Environ Res 161:409-417. https://doi.org/10.1016/jenvres.2017.11.023

61. Couture A, Levesque B, Dewailly É, Muckle G, Déry S, Proulx J-F (2012) Lead exposure in Nunavik: from research to action. J Circumpolar Health 71:18591. https://doi.org/10.3402/ijch.V71i0.18591

62. Johansen P, Pedersen HS, Asmund G, Riget F (2006) Lead shot from hunting as a source of lead in human blood. Environ Pollut 142:93-97. https:// doi.org/10.1016/j.envpol.2005.09.015

63. Uhart M, Ferreyra HdV, Romano M, Muchiutti A, Alzuagaray S, Santiago M, Caselli A (2019) Lead pollution from hunting ammunition in Argentina and current state of lead shot replacement efforts. Ambio 48:1015-1022. https://doi.org/10.1007/s13280-019-01178-x

64. Bodeau-Livinec F, Glorennec P, Cot M, Dumas P, Durand S, Massougbodji A, Ayotte P, Le Bot B (2016) Elevated blood lead levels in infants and mothers in Benin and potential sources of exposure. Int J Environ Res Public Health 13:316. https://doi.org/10.3390/ijerph13030316

65. Hampton JO, Laidlaw M, Buenz E, Arnemo JM (2018) Heads in the sand: public health and ecological risks of lead-based bullets for wildlife shooting in Australia. Wildl Res 45:287-306. https://doi.org/10.1071/WR17180

66. BASC (2020) British Association for Shooting and Conservation. A joint statement on the future of shotgun ammunition for live quarry shooting. https://basc.org.uk/a-joint-statement-on-the-future-of-shotgun-ammun ition-for-live-quarry-shooting/. Accessed 24 Feb 2020

\section{Publisher's Note}

Springer Nature remains neutral with regard to jurisdictional claims in published maps and institutional affiliations. 